\title{
新生児に発生したガマ腫と甲状舌管䨢胞様病変の合併例
}

\author{
瀬古和秀·各務秀明 · 光藤健司 ·水谷英樹 \\ 上田実・金田敏郎
}

\section{Co-existence of ranula and possible thyroglossal duct cyst in a newborn baby}

\author{
Kazuhide SeKo $\cdot$ Hideaki Kagami $\cdot$ Kenji Mitsudo $\cdot$ Hideki Mizutani \\ Minoru UEDA $\cdot$ Toshio KanEDA
}

\begin{abstract}
In this paper, we report a case of congenital ranula lying adjacent to a possible thyroglossal duct cyst. The patient was a newborn baby who presented no remarkable anomalies in other regions. He was referred to us by a gynecologist because of swelling of the oral floor and elevation of the tongue. There were no noteworthy findings in the patient's family or personal history, including during gestation. Our clinical diagnosis was a sublingual cyst. The cyst was surgically enucleated at 9 months old when his body weight reached $9 \mathrm{~kg}$. The cyst consisted of two compartments, one superficial and the other deep, which were completely separate. From clinical and pathological findings, the superficial portion was diagnosed as a congenital ranula, and the deep cyst was supposed to be a thyroglossal duct cyst. A close etiological relationship was suggested between these two adjacent cysts.
\end{abstract}

Key words: ranula (ガマ腫), retention cyst（貯留裹胞), thyroglossal duct cyst (甲状舌管裹胞), newborn baby（新生児）

\section{緒言}

新生児に発生する口底部囊胞としては貯留囊胞, 類 皮震胞などの例が報告されている1,2).

そして貯留囊胞に他の囊胞が接して見られたとの報 告は稀であるが3)，今回われわれは，新生児の口底部 に存在したガマ腫を含む 2 つの囊胞の合併例を経験し た. 双方の位置関係からも両襄胞の発生に関して密接 な関係が推測された症例であったため, その概要を報 告する.

名古屋大学医学部口腔外科学講座

(主任 : 上田実教授)

Department of Oral Surgery, Nagoya University School of Medicine (Chief: prof. Minoru Ueda)

受付日: 平成 6 年 4 月 25 日

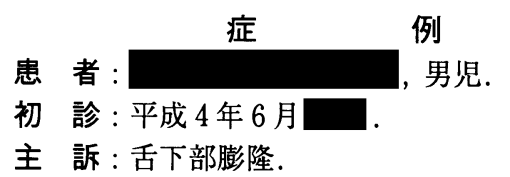

現病歴: 出生当日, 産婦人科医師により舌下部膨隆 を指摘され, 当科に紹介された。この時点で呼吸困難 を呈することはなかった。

妊娠歴：妊娠中に特記事項なし.

家族歴 : 特記事項なし.

全身所見：生下時体重 $2880 \mathrm{~g}$, Apgar score 9, 心 拍, 体温とも正常, 全身所見に異常は認めなかった.

局所所見：口底部に健常粘膜に被覆された $20 \times 20$ $\mathrm{mm}$ 大の半球様, 境界明瞭な腫脹を認め, 波動を触知

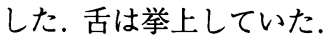

臨床診断 : 口底部䡛胞.

処置および経過：上記診断のもとに外科的摘出術を 計画したが, 舌の挙上によって呼吸困難, 哺乳障害を 


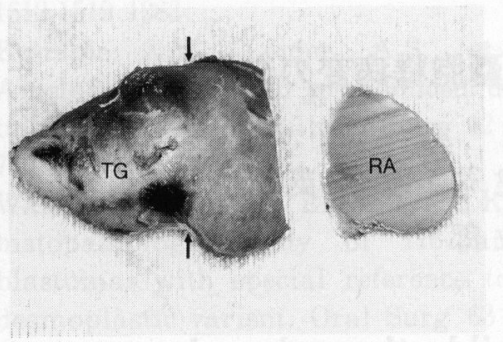

写真 1 摘出物所見

襄胞は寒天材の注入された浅部とされ ていない深部からなる 2 胞性を示す. (矢印は両囊胞の境界を示す.)

$\mathrm{TG}$ : 甲状舌管譲胞梯病変

RA: ガマ腫

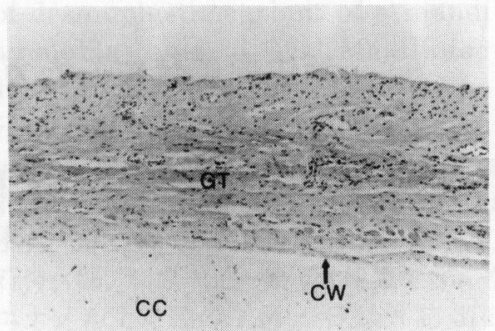

写真 2 摘出物浅部の病理組織像

(H-E 染色, $\times 400)$

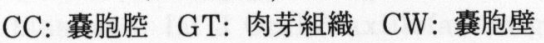

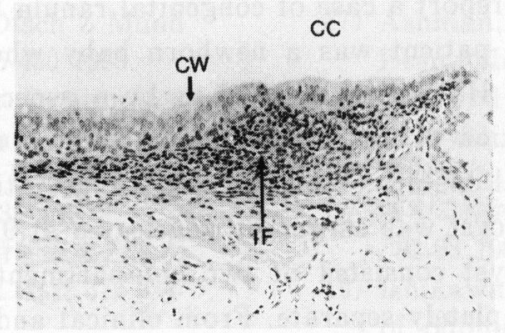

写真 3 摘出物深部の病理組織像

$(\mathrm{H}-\mathrm{E}$ 染色, $\times 400)$

CC: 震胞壁

$\mathrm{CW}$ : 線毛上皮に被覆された襄胞壁

IF：炎症細胞の浸潤

呈することはなかったため, 患児の手術に対する適応 力を考慮し，しばらく経過観察を行った.

病変は経過観察中特に変化は示さなかったものの, 依然として舌の挙上は認められた。

体重が $9 \mathrm{~kg}$ に達した平成 5 年 3 月】全身麻酔下 にて囊胞摘出術を施行した. 嚢胞壁を保護し摘出を容 易にするために寒天注入法 4 )を用いた. 穿刺により淡 黄色粘绸な濃汁様内溶液を $2.0 \mathrm{ml}$ 吸引したのち, 同部 より寒天材を注入した，襄胞壁は周囲の口腔粘膜を含 め鈍的に剥離摘出を行った. 霊胞壁と周囲の口腔粘膜 との間に癒着は認めなかった. 摘出された嚢胞は 2 胞 性で寒天材の注入された浅部と, 注入されていない深 部に分かれていた（写真 1 ). 浅部に存在した囊胞よ り吸引された内溶液は, アミラーゼが 2945 単位と高 值を示し唾液が主成分であると推測された。 また深部 に存在した囊胞は舌下腺との関連は見られず舌筋内に 存在していた.
病理組織学的所見 : 摘出物浅部は肉芽組織からなる 囊胞壁を有し，上皮を欠く偽囊胞であった（写真 2 ）. 摘出物深部は線毛円柱上皮に被覆された棗胞壁を有し, 一部出血と炎症細胞の浸潤を認めた (写真 3 ). 2 つ の囊胞は疎な結合組織により接していたが 2 つの囊胞 腔は完全に分離されていた. 臨床所見と合わせ検討し たところ摘出物浅部はガマ腫と考えられた. 深部の震 胞については今回の所見のみから断定することは困難 であるが部位および組織像から甲状舌管囊胞と推測さ れた. 現在術後 13 か月を経過するも病変の再発はな く経過良好である。

\section{考}

貯留襄胞の成因については, 古くから異物または炎 症による導管ないし腺房の閉鎖が重視されていた ${ }^{5}$ ). しかし近年の実験的研究から,この囊胞は導管の単な る閉鎖による分泌物の停滞による導管拡張の結果では 生じないことが確認されている。一方，導管の損傷に 
よって周囲の組織中に唾液が溢出することにより同様 の病変が起こることが明らかになった 6,7 ).

しかし，新生児においては，これら誘発原因に接す る機会は少なく，その成因についても導管損傷に結果 というよりむしろ導管の先天性異常によるのではない かと考えられている8).

今回われわれは新生児の口底部に貯留䩧胞とそれに 接して存在した甲状舌管襄胞様病変を経験した。 $2 つ$ の囊胞間の関連についてはわれわれの涉猟しえた文献 等にも記載はないが, Thompson らは鳃囊胞に接し て存在したガマ腫の症例を報告している ${ }^{3)}$.この例で は鰓䡛胞が鰓弓中の筋の変形をもたらしたことにより 唾液腺導管を変形, 変移させたことが一因ではないか と推定している.この例が今回の症例と直接対応する かは疑問であるが, 同様の機序を考えれば，先天的に 存在した甲状舌管囊胞様病変が, 近接した喠液腺導管 を圧迫，もしくは器質的変化をもたらすことにより， ガマ腫を生じせしめたのではないかと推測された。し かし組織学的検索にても, その機序を証明するにはい たらず，その関係の解明は，今後の課題と考えられた。 また新生児貯留襄胞の診断に際しては唾液腺導管の圧 迫，損傷を惹起させるうる合併疾患の可能性に，十分 な配慮が必要と考えられた。

\section{結語}

今回われわれは新生児の口底部に存在したガマ腫と それに近接して存在した甲状舌管襄胞様病変を経験し
たので，文献的考察を加えその概要を報告した。

\section{引用文 献}

1) Rocco, R.A: Congenital cystic dilatation of the submandidular duct. Oral Surg 59 : 656-658 1984.

2) Rees, R: Congenital ranula. Br Dent $J$ 146 : 345-346 1979 .

3) Thompson, J.E: The relationship between ranula and branchiogenetic cysts. Ann Surg $72: 164-1721920$.

4）藤本雄大, 宇佐美雄司, 他 : 寒天印象材を用い た軟組織内裹胞の摘出手術. 日口外誌 $39: 487$ 4891993.

5）石川悟朗監修: 口腔病理学 II. 改訂版, 末永書 店, 京都, 1982, 886 頁.

6) Whitlock, R.I.H and Summersgill, G.B: Ranula with cervical extensions. Report of a case. Oral Surg Oral Med and Oral Path $15: 11631962$.

7) Bhaskar, S.N., Bolden, T.E., et al.: Pathogenesis of mucoceles. J D Res $35: 863$, 1956.

8) Pownell, P.H., Brown, O.E., et al.: Congenital abnormalities of the submandibular duct. Int J Pediatr Otorhinolaryngology 24 : 161-169 1992. 